\title{
Physiological factors underlying the formation of ovarian follicular fluid
}

\author{
R. G. Gosden, R. H. F. Hunter*, Evelyn Telfer, C. Torrance and N. Brown \\ Department of Physiology, University Medical School, Teviot Place, Edinburgh EH8 9AG and \\ * School of Agriculture, University of Edinburgh, EH9 3JG, U.K.
}

Keywords: follicles, ovary, antrum, fluid, development

\section{Introduction}

In common with all other cells, the oocyte and granulosa cells are bathed in extracellular fluid. It has, however, become conventional to reserve the term 'follicular fluid' for that fraction of the extracellular fluid that accumulates in the antrum of larger follicles. This pool of fluid is of considerable biological significance since its composition indicates the environment in which the oocyte and granulosa cells are growing and maturing. Furthermore, it buffers the internal environment of the follicle against the influence of external conditions presented by the blood stream.

The chemical composition of follicular fluid has been studied extensively and found to consist of substances derived from blood as well as from local secretion and metabolism. Particular attention has been paid to the proteins and hormonal steroids. Rather than attempt a comprehensive review, this paper will focus on general physical characteristics of the fluid and the physiological factors that influence its formation. These properties determine the rate at which extracellular fluid is accumulating and, hence, the size and morphogenesis of the Graafian follicle. It is important to reveal the mechanism and dynamics of follicular fluid formation if the composition of the fluid is to be fully understood.

\section{Ontogenesis of the follicular antrum}

Follicles do not possess a major pool of extracellular fluid from the beginning of their development. The primordial follicle consists of a relatively small oocyte surrounded by a single layer of squamous cells which are destined to become the granulosa cell layer (membrana granulosa). Pools of follicular fluid appear when the granulosa cells have passed through about 11-12 mitotic cycles and a solid follicle containing 2000-3000 cells and with a diameter of 150-400 $\mu \mathrm{m}$ has been built. These pools coalesce to form a single spherical cavity, the antrum, which is central and bounded by a layer of granulosa cells of uniform thickness except at the pole where cumulus cells are attached. The antrum characterizes the mature follicles of most mammals but it is not universally found. Ovulation is said to occur from 'solid' follicles in a number of insectivores (Mossman \& Duke, 1973). These ovulations occur precociously because the follicles scarcely exceed the dimensions at which the antrum would normally form.

\section{Quantitative aspects of follicular fluid formation}

There is evidence which suggests that the size of follicles at the time of antrum formation varies with body size (Parkes, 1932; McNatty, 1978) although the raw data show that variation within a species is of a magnitude similar to that between species. There can be no doubt however that the 
size of follicles shortly before ovulation varies with body size. When the volume of a preovulatory set of follicles is plotted against body weight on logarithmic axes, an isometric relationship is obtained (Gosden \& Telfer, 1987). Most of this volume is extracellular space except in a few species in which the small follicles contain a diminutive antrum (e.g. Sorex araneus). Body size is not the sole arbiter of Graafian follicle volume since relatively small follicles occur in species that release prodigious numbers of eggs, although the collective volume remains commensurate with body weight (Weir, 1971). The size of the mature Graafian follicle is genetically determined and is of physiological significance. The volume of the antrum will influence the concentration of hormones and metabolites in the extracellular fluid and, consequently, their biological actions. Formation of the antrum requires the combined actions of FSH and oestrogen (Goldenberg et al., 1972) and it is anticipated that the volume changes will also be regulated by polypeptide and/or steroid hormones. In this regard, it may be significant that the concentrations of oestrogen and androgen in the antrum are very different in follicles that are expanding compared with those that are shrinking (atretic) (McNatty et al., 1979).

After Robinson (1918), it has been customary to distinguish three phases of follicular fluid formation. Primary fluid ("liquor") is produced until shortly before ovulation when the rate of accumulation rises abruptly. Secondary fluid is produced at this time, and presumably under the influence of the surge of gonadotrophic hormones. Tertiary fluid is produced in the collapsed follicle after ovulation. Robinson regarded primary fluid as having an intracellular origin whereas secondary fluid has been attributed to transudation from the thecal capillaries, a conclusion which has been upheld by many later commentators. Much less attention has been given to tertiary fluid; it will not be considered further here.

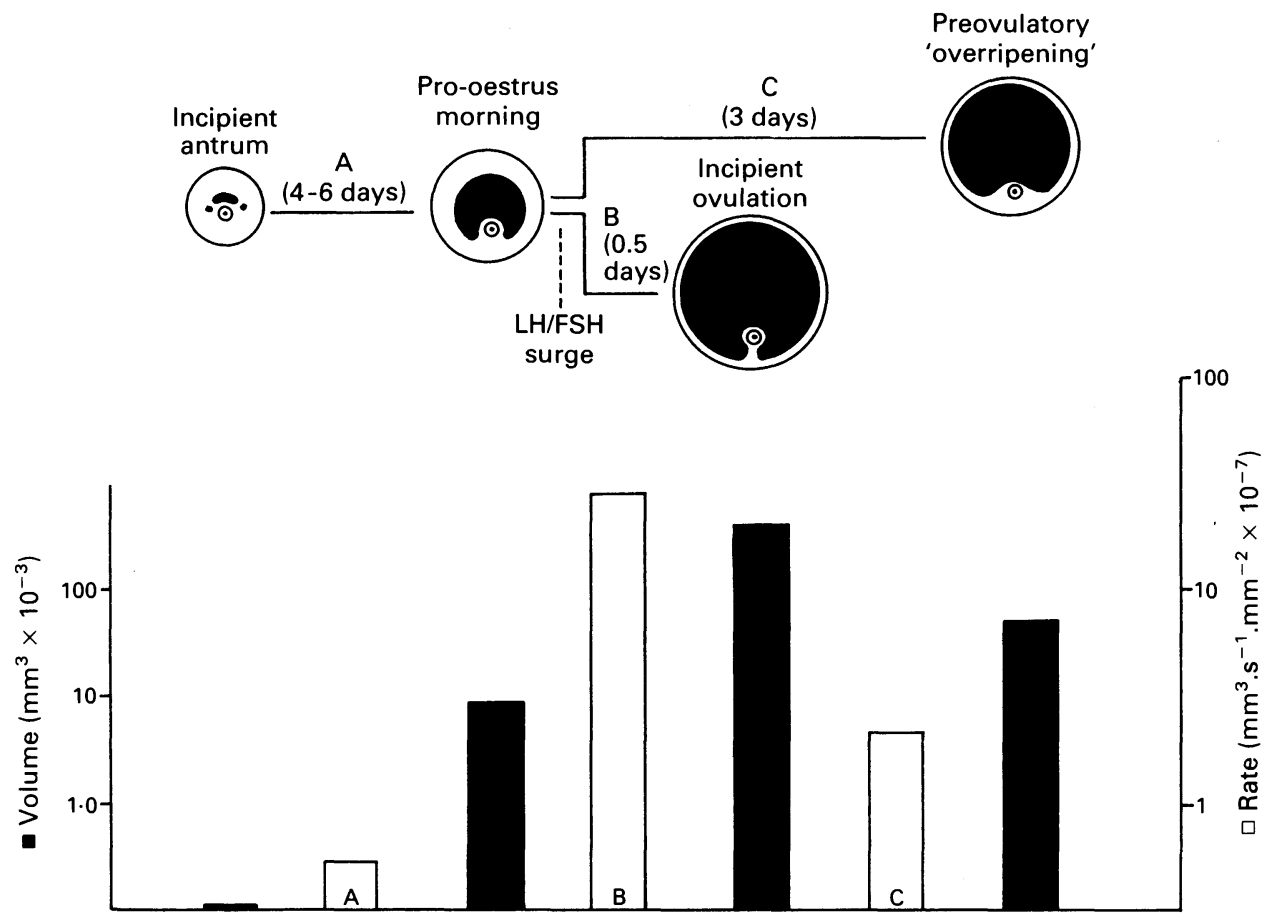

Fig. 1. The upper panel depicts the expansion of the antrum in mouse follicles which are either proceeding to ovulation (A-B) or, in the absence of an ovulatory stimulus, to formation of a follicular cyst $(\mathrm{A}-\mathrm{C})$. The lower panel represents the volume of the antrum at different stages and the estimated rates of fluid accumulation expressed on logarithmic axes. Measurements are based on histological sections and assume linear rates of growth. 


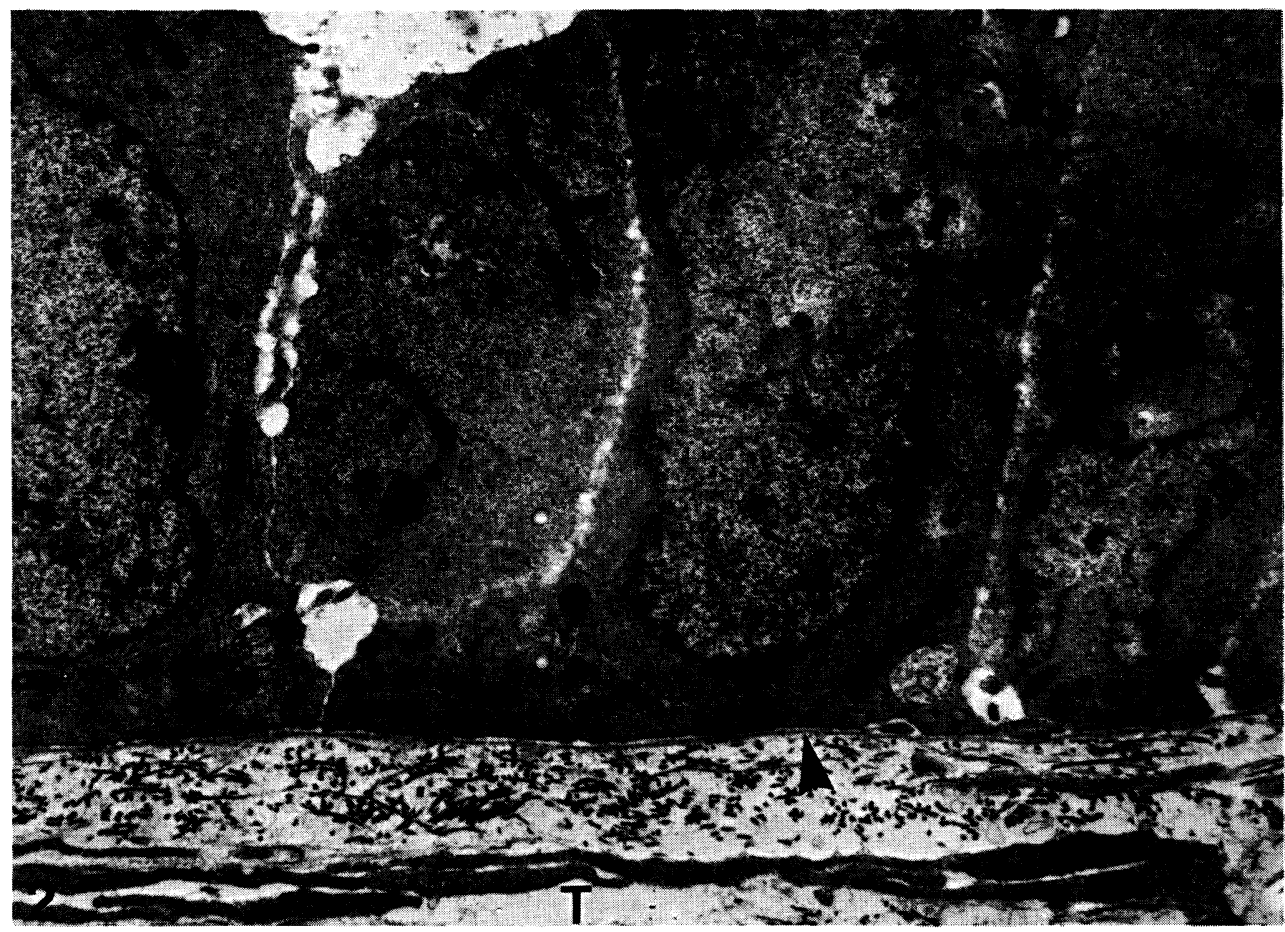

Fig. 2. The ultrastructural appearance of the peripheral layer of granulosa cells which rest on a basement membrane (arrow) in this rabbit follicle. The vascular theca (T) lies on the opposite side of this membrane. $\times 9000$.

In view of the long-established distinction between primary and secondary fluids it is surprising that this has not been quantified. The volume of the antrum and rate at which it is expanding can be estimated simply by making measurements of tissue sections. It is assumed that artefactual shrinkage is a minimal and constant factor and that the rate of expansion is more-or-less constant at each phase. Results which were obtained from mouse ovaries have verified the distinction between the fluids (Fig. 1). When standardized for differences in surface area, the results indicate that the rate of extracellular fluid formation during preovulatory swelling rises about 50 -fold above that of the previous phase. When the gonadotrophin surge is lacking, swelling continues (Laing et al., 1984), but it is at a slower rate than that of follicles undergoing preovulatory activation, strengthening suspicion that hormones stimulate this process (Fig. 1). Antral follicles take much longer to grow to full size in large species than in small ones. Calculations based on data obtained by Turnbull et al. (1977) and Driancourt et al. (1986) for the sheep indicate that a distinction can be made between the rates of primary and secondary fluid formation, these being of the same order of magnitude as in mice. By comparison with the secretion/absorption of fluids across many other membranes, the rate of follicle swelling is sluggish, adding to the practical difficulties of investigating its formation. In, for example, the anterior chamber of the eye, aqueous humour is produced at a rate of about $2 \mu \mathrm{l} . \mathrm{min}^{-1}$ whereas the corresponding value for ovine follicular fluid during the preovulatory phase is $20 \mu$ lday $^{-1}$.

\section{The membrana granulosa: an epithelial layer}

Epithelial cells either line cavities or cover surfaces of the body and, as a consequence of their location, can regulate the internal environment of body compartments. These cells are therefore 


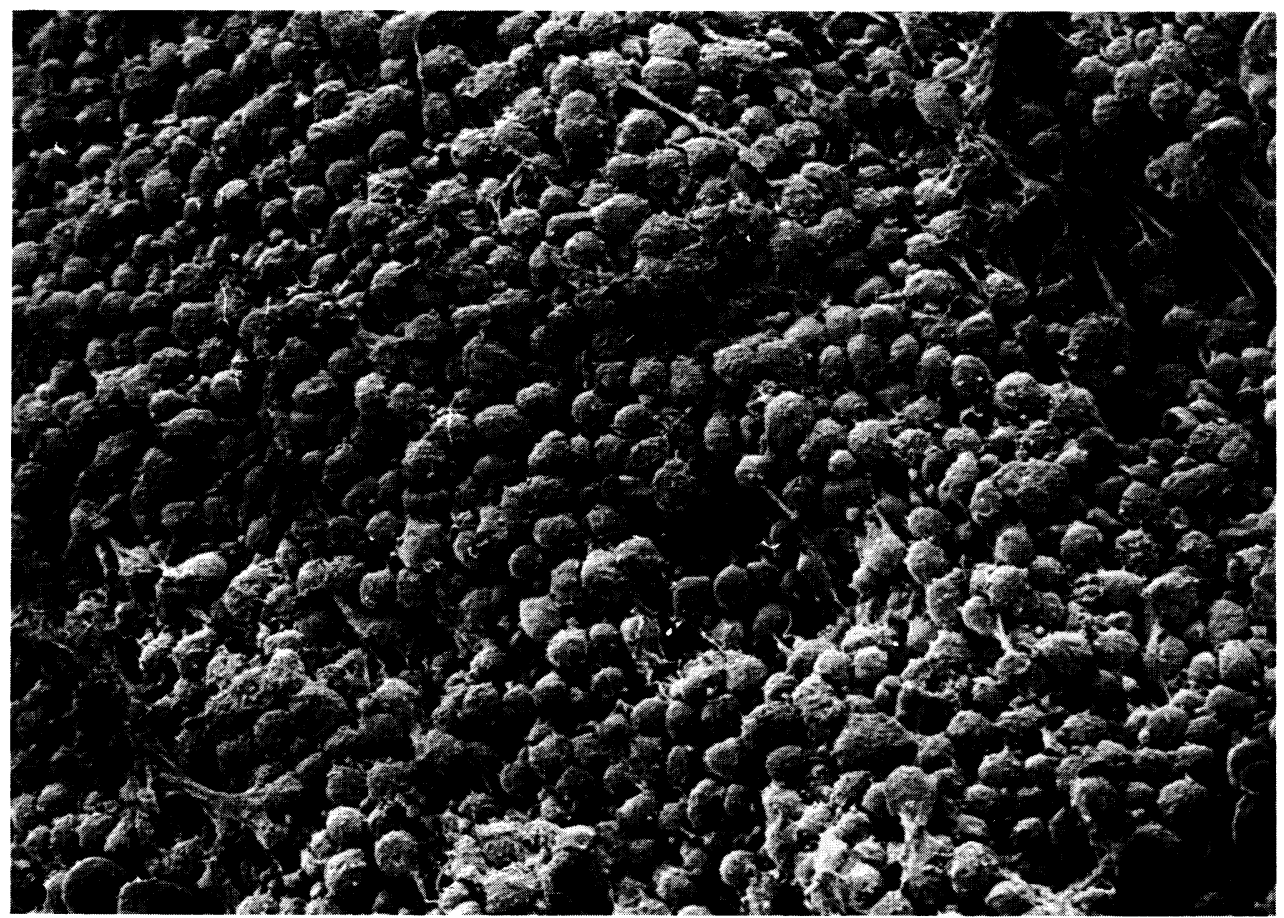

Fig. 3. Scanning electron micrograph of the inner surface of the mural epithelium of a sheep Graafian follicle. The granulosa cells present a regular mosaic with relatively smooth surfaces. No large channels are visible opening into the antrum. $\times 2025$.

expected to be specialized for promoting/restricting the movements of particular ions and molecules between compartments. Since granulosa cells are an epithelial type, they may be expected to exhibit these functions. The granulosa cells of growing follicles are typically polygonal although the outer layer is columnar and rests on a delicate basement membrane (Fig. 2). Up to about 10 cell layers develop in preantral follicles but these attenuate when the antrum expands because the follicle wall is compliant and mitotic activity has virtually ceased. The epithelial surface facing the antrum is relatively featureless: it is uniform and lacking in conspicuous channels or processes (Fig. 3). The granulosa layer is the same thickness throughout except at the pole containing the cumulus oophorus in which cellular proliferation continues (Gosden et al., 1983).

The morphology of the follicular epithelium suggests a structure that is highly permeable to water and dissolved substances. In contrast to so-called 'tight' epithelia (e.g. frog skin, toad bladder, trophectoderm), occlusive junctions are not found between cells, although other junctional complexes exist for maintaining structural integrity and intercellular communication (Albertini \& Anderson, 1974; Fig. 4). Granulosa cells are separated by channels measuring $20 \mathrm{~nm}$ which permit molecules of up to $M_{\mathrm{r}} 500000$ in size to penetrate and reach the antrum (Zachariae, 1958; Albertini \& Anderson, 1974; Payer, 1975; Cran et al., 1976). The density of cell packing decreases centripetally and is further reduced in the cumulus cells during mucification. Thus, the extracellular fluid of the follicle is a continuum and sub-compartments are not well-defined by structural barriers. Hence, many potentially toxic substances carried in blood can reach the oocyte (Baukloh et al., 1985).

Small spherical spaces containing extracellular fluid appear in the granulosa layer of some species when the antrum is incipient. The significance of these Call-Exner bodies is not known although it has been suggested that they are sites of active secretion of follicular fluid (Brambell, 1956) and may be related to the enlargement of the Golgi apparatus (Hadek, 1963). A major 
role is doubtful because they remain separate from pools of primary follicular fluid and exist independently of an antrum in human granulosa cell tumours.

\section{Chemical composition of follicular fluid}

Chemical studies of secondary fluid have been encouraged by accessibility in large follicles. There is, however, a paucity of information about primary fluid in small follicles $(<1 \mathrm{~mm})$ and the extent to which the composition of these fluids differs remains unclear. Particular attention is being paid here to electrolytes since the organic components of follicular fluid have been reviewed thoroughly elsewhere (Edwards, 1974; McNatty, 1978; Lenton, 1988).

Table 1 shows the concentrations of the principal electrolytes in large (mainly preovulatory) follicles of 5 species together with the values for plasma/serum. No major concentration gradient exists across the follicle wall. There is tentative evidence, particularly from smaller follicles, that the concentrations of $\mathrm{K}^{+}$are greater in follicular fluid than in blood. This interesting finding parallels the situation in the oviduct (Borland et al., 1980) and could indicate active inward transport of the cation. It requires verification because the possibilities that either $\mathrm{K}^{+}$had leaked from damaged cells or that atretic follicles had been sampled were not excluded. Furthermore, any results obtained with fluids obtained post mortem must be considered unreliable because of the rapid changes that take place (Edwards, 1974; Knudsen et al., 1978). In view of variable sample quality, earlier claims that electrolyte concentrations during the ovarian cycle and at different stages of follicle development require re-examination. Measurements of $\mathrm{Na}^{+}$are probably more reliable that those of $\mathrm{K}^{+}$because this cation is abundant in extracellular fluid but scarce in cells. The slight, but significant, elevation
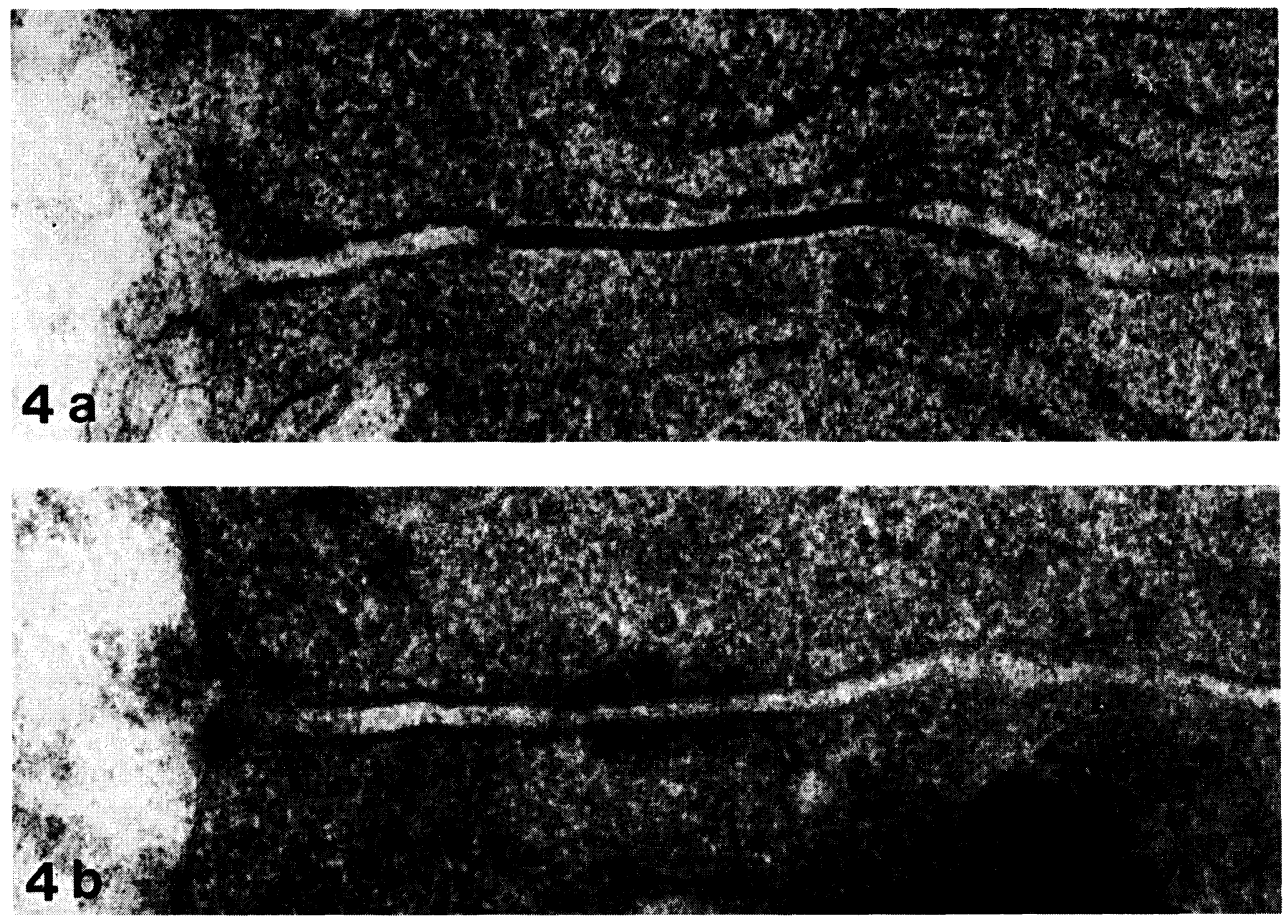

Fig. 4. Channels between adjacent granulosa cells are visible in this rabbit Graafian follicle. The cells are connected by a junctional apparatus resembling (a) gap junctions and (b) maculae adhaerens. $\times 90000$. 


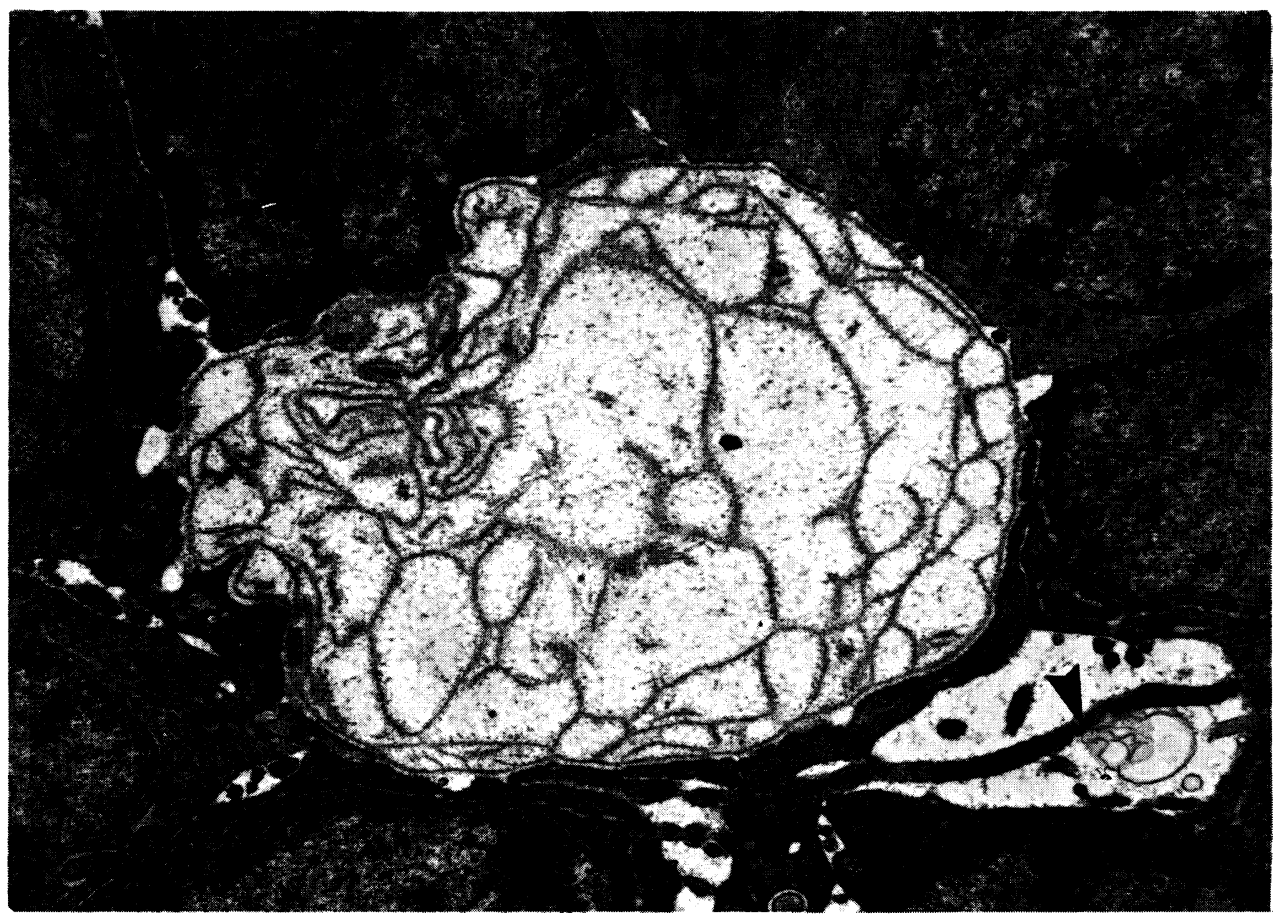

Fig. 5. A Call-Exner body situated in the wall of a rabbit Graafian follicle. These structures frequently contain long strands of moderately electron dense material suspended in the extracellular fluid and in apposition to the epithelial cells. The apical faces of these cells are smooth although there are long processes in the vicinity (arrow). $\times 10000$.

Table 1. Electrolyte concentrations (mmol. $\left.\mathrm{l}^{-1}\right)$ in the fluids of large follicles (FF) as compared with plasma (P) or serum (S)

\begin{tabular}{|c|c|c|c|c|c|c|c|c|c|c|c|}
\hline \multirow[b]{2}{*}{ Species } & \multicolumn{2}{|c|}{$\mathrm{Na}^{+}$} & \multicolumn{2}{|c|}{$\mathrm{K}^{+}$} & \multicolumn{2}{|c|}{$\mathrm{Cl}^{-}$} & \multicolumn{2}{|c|}{$\mathrm{Ca}^{2+}$} & \multicolumn{2}{|c|}{$\mathrm{Mg}^{2+}$} & \multirow[b]{2}{*}{ Reference } \\
\hline & $\mathrm{FF}$ & $\mathrm{P} / \mathrm{S}$ & FF & $\mathrm{P} / \mathrm{S}$ & $\mathrm{FF}$ & $\mathrm{P} / \mathrm{S}$ & $\mathrm{FF}$ & $\mathrm{P} / \mathrm{S}$ & FF & $\mathrm{P} / \mathrm{S}$ & \\
\hline Human & $\begin{array}{l}124 \\
143\end{array}$ & $\begin{array}{l}145 \\
154\end{array}$ & $\begin{array}{l}4 \cdot 4 \\
5 \cdot 4\end{array}$ & $\begin{array}{l}4 \cdot 6 \\
5 \cdot 4\end{array}$ & $\begin{array}{l}109 \\
140\end{array}$ & $\begin{array}{l}104 \\
146\end{array}$ & 0.94 & $1 \cdot 04$ & 0.76 & 0.68 & $\begin{array}{l}\text { Shalgi et al. (1972) } \\
\text { Chong et al. (1977) }\end{array}$ \\
\hline Rabbit & $\begin{array}{l}133 \\
140\end{array}$ & $\begin{array}{l}125 \\
136\end{array}$ & $\begin{array}{l}7 \cdot 0 \\
6 \cdot 2\end{array}$ & $\begin{array}{l}4 \cdot 3 \\
5 \cdot 7\end{array}$ & $\begin{array}{l}136 \\
144\end{array}$ & $\begin{array}{l}127 \\
139\end{array}$ & 3.56 & 3.85 & 1.40 & 1.67 & $\begin{array}{l}\text { David et al. (1973) } \\
\text { Burgoyne et al. (1979) }\end{array}$ \\
\hline Sheep & 149 & 149 & $4 \cdot 7$ & 4.9 & 107 & 106 & $2 \cdot 29$ & $2 \cdot 28$ & 0.89 & $0 \cdot 87$ & $\begin{array}{l}\text { R.G. Gosden \& R.H.F } \\
\text { Hunter (unpublished) }\end{array}$ \\
\hline \multirow[t]{3}{*}{ Pig } & 128 & 143 & $15 \cdot 9$ & $5 \cdot 2$ & & & & & & & $\begin{array}{l}\text { Schuetz \& Anisowicz } \\
(1974)^{*}\end{array}$ \\
\hline & 142 & 147 & $\begin{array}{l}7 \cdot 6 \\
4.9\end{array}$ & $\begin{array}{l}7 \cdot 1 \\
4 \cdot 8\end{array}$ & & & $10 \cdot 3$ & $10 \cdot 8$ & & & Chang et al. $(1976)^{*}$ \\
\hline & 141 & 138 & 3.8 & $3 \cdot 8$ & $97 \cdot 3$ & $95 \cdot 7$ & $2 \cdot 30$ & $2 \cdot 27$ & 0.75 & 0.77 & $\begin{array}{l}\text { R.G. Gosden \& R.H.F } \\
\text { Hunter (unpublished) }\end{array}$ \\
\hline Cow & 132 & & $9 \cdot 2$ & & $149 \cdot 5$ & & $3 \cdot 1$ & & & & $\begin{array}{l}\text { Olds \& VanDemark } \\
(1957)^{*}\end{array}$ \\
\hline
\end{tabular}

${ }^{*}$ Follicular fluids were obtained post mortem. 
of $\mathrm{Na}^{+}$in follicular fluid of some species (e.g. pig, rabbit), although not all (e.g. sheep), may result from active transport processes (see below). No concentration gradients have been identified for the other ions $\left(\mathrm{Cl}^{-}, \mathrm{Ca}^{2+}, \mathrm{Mg}^{2+}\right)$.

These results together with those obtained with many small organic molecules strengthen the conclusion that most substances can diffuse freely into or out of the follicle. This does not need to imply, however, that equilibrium conditions exist; indeed, this is doubtful since the follicle is never static because of continuous changes in volume and metabolism.

The protein concentrations have attracted most attention because hormones have to gain entry to the follicle to influence the granulosa cells. In toto they range from 50 to $100 \%$ of normal plasma values but they are not present in equimolar proportions (McNatty, 1978). Larger proteins penetrate more slowly than small ones and the concentrations present at a particular stage can be expected to vary with the flux of water, the surface area to volume ratio of the follicle and the permeability of the thecal blood vessels. Follicular fluid contains most of the plasma proteins, albumin being the most abundant in both cases. Plasma proteins of $M_{\mathrm{r}} \geqslant 850000$ are absent (Shalgi et al., 1973) and some large molecules produced by granulosa cells (e.g. proteoglycans) probably do not escape from the follicle (Ax \& Ryan, 1979). The follicular wall therefore behaves like a coarse molecular sieve and a blood-follicle barrier exists. The gonadotrophins, FSH and LH, are not excluded by this barrier, although present at lower concentrations than in blood (McNatty et al., 1975).

\section{Respiratory gases and acid-base balance}

Oocytes are isolated from the capillary circulation because the follicular epithelium is avascular. As a consequence of diffusion through layers of respiring cells, the concentration of oxygen around the oocyte is expected to be attenuated to an extent which will vary with the size and form of the follicle. A steeply descending inward concentration gradient has been predicted for large preantral follicles by a simple mathematical model (Gosden \& Byatt-Smith, 1986) but Graafian stages are not so amenable to modelling because of their multicompartmental structure and asymmetry. Until direct measurements of the $\mathrm{PO}_{2}$ can be made, inferences will have to be drawn from the analysis of follicular fluid whilst recognizing that these values could be substantially different from those of the local environment of the oocyte.

Table 2. The composition of follicular fluid with respect to blood gases, bicarbonate and $\mathrm{pH}$

\begin{tabular}{lccccl}
\hline Species & $\mathrm{PO}_{2}(\mathrm{mmHg})$ & $\mathrm{PCO}_{2}(\mathrm{mmHg})$ & $\mathrm{HCO}_{3}^{-}\left(\mathrm{mmol}^{-1}\right)$ & $\mathrm{pH}$ & \multicolumn{2}{c}{ Reference } \\
\hline Human & $54 \cdot 3$ & $35 \cdot 1$ & - & $7 \cdot 27$ & Shalgi et al. $(1972)$ \\
Human & $103 \cdot 5$ & $43 \cdot 2$ & - & $7 \cdot 34$ & Fraser et al (1973) \\
Pig & 51 & 45 & $28 \cdot 0$ & $7 \cdot 41$ & Knudsen et al. (1978) \\
Pig & - & $52 \cdot 1$ & $27 \cdot 3$ & $7 \cdot 34$ & $\begin{array}{l}\text { R.G. Gosden \& R.H.F. Hunter } \\
\text { (unpublished) }\end{array}$ \\
\hline
\end{tabular}

Respiratory gas tensions in follicular fluid have seldom been measured and the available data are highly variable (Table 2). Much of this variability is probably artefactual because there are several sources of potential error. The data are, however, sufficiently consistent to conclude that the fluid is not anoxic and the $\mathrm{PO}_{2}$ may even be close to that of normal ovarian venous blood. Clarification is required. Measurements of the $\mathrm{PCO}_{2}$ and $\mathrm{pH}$ are within the venous range and more consistent. Since follicular fluid has a similar composition to plasma, the $\mathrm{pH}$ will be buffered by carbonic 
acid and protein (Shalgi et al., 1972). The $\mathrm{pH}$ of the extracellular fluid, which is $7 \cdot 3-7 \cdot 4$ in the antrum, may differ locally as a result of differences in metabolism and secretion, e.g. hyaluronic acid and chondroitin sulphuric acid.

\section{Physiology of follicular fluid formation}

The morphological and chemical evidence discussed so far leads to the expectation that most molecules will move freely across a porous follicular wall according to their concentration gradient. They stengthen the early view that transudation from capillaries is responsible for secondary (and perhaps other) follicular fluid (Robinson, 1918; Burr \& Davies, 1951). The possibility remains, however, that more than one mechanism exists for the transport of fluid, as is the case in other 'leaky' epithelia. In the gall bladder active outward transport of salt is followed by the net movement of water down its osmotic gradient (Spring \& Ericson, 1982). A similar mechanism, perhaps controlled by hormones, could explain the formation of follicular fluid provided that the polarity of salt transport was reversed. An alternative suggestion has been made that hydrolysis of polymeric glycosaminoglycans in the antrum could raise the osmotic potential and cause follicles to swell, leading to ovulation (Zachariae, 1957; Zachariae \& Jensen, 1958). Either hypothesis would explain why the shrinkage of the antrum and pycnosis of mural granulosa cells occur concurrently in atretic follicles. The latter one is no longer favoured, however, because the colloid osmotic pressure is not elevated during the preovulatory phase and ovulation occurs without a raised intrafollicular pressure (see below). The question of whether salt transport is involved has not been answered. It appears that follicles possess osmotic properties because they shrink when immersed in hypertonic saline, demonstrating that the epithelium is sufficiently semipermeable.

The rate and direction of net water movement between the two compartments, namely plasma (strictly interstitial fluid/lymph) and follicular fluid, depends on the magnitude and sign of their chemical potentials. In the absence of temperature or hydrostatic pressure gradients these potentials are predicted by the depression of the freezing point of the fluids. The extracellular fluids of the sheep ovary are isotonic, with an osmotic pressure equivalent of 300 mosmol. $\mathrm{kg}^{-1}$ (Table 3). Whilst this result appears to deny that water enters the follicle as an osmotic consequence of secretion of solutes into the antrum, there is evidence that gradients $<1$ mosmol. $\mathrm{kg}^{-1}$ can produce substantial water transport (Spring \& Ericson, 1982). In view of the slow accumulation of follicular fluid, particularly at early stages, it is not justifiable to dismiss the active transport hypothesis.

Table 3. Freezing point depression $\left({ }^{\circ} \mathrm{C}\right)$ of ovarian fluids from sheep measured using a modified Ramsay-Brown apparatus (Ramsay \& Brown, 1955) using a quartz crystal thermometer sensitive to $1 / 1000^{\circ} \mathrm{C}$ (unpublished data)

\begin{tabular}{|c|c|c|c|}
\hline \multirow{2}{*}{$\begin{array}{l}\text { Ovarian venous } \\
\text { plasma }\end{array}$} & \multirow{2}{*}{$\begin{array}{l}\text { Ovarian } \\
\text { lymph }\end{array}$} & \multicolumn{2}{|c|}{ Follicular fluid } \\
\hline & & Follicle $>6 \mathrm{~mm}$ diam & Follicle $2-6 \mathrm{~mm}$ diam. \\
\hline$-0.557 \pm 0.006$ & $-0.587 \pm 0.021$ & $-0.548 \pm 0.005$ & $-0.551 \pm 0.005$ \\
\hline
\end{tabular}

Values are mean \pm s.e.m. for $7-11$ observations.

If an osmotic gradient is being considered the $\mathrm{Na}$ ion is the prime candidate for active transport because of its abundance and the established role of the $\mathrm{Na}, \mathrm{K}$-ATPase in water transport in some epithelia. This suggestion is supported by the slight excess of $\mathrm{Na}$ in the antral fluid of some species and the binding of ouabain to granulosa cell membranes (R. G. Gosden, unpublished). The fact that granulosa cell monolayers do not form domes of secreted fluid, as do other transporting 


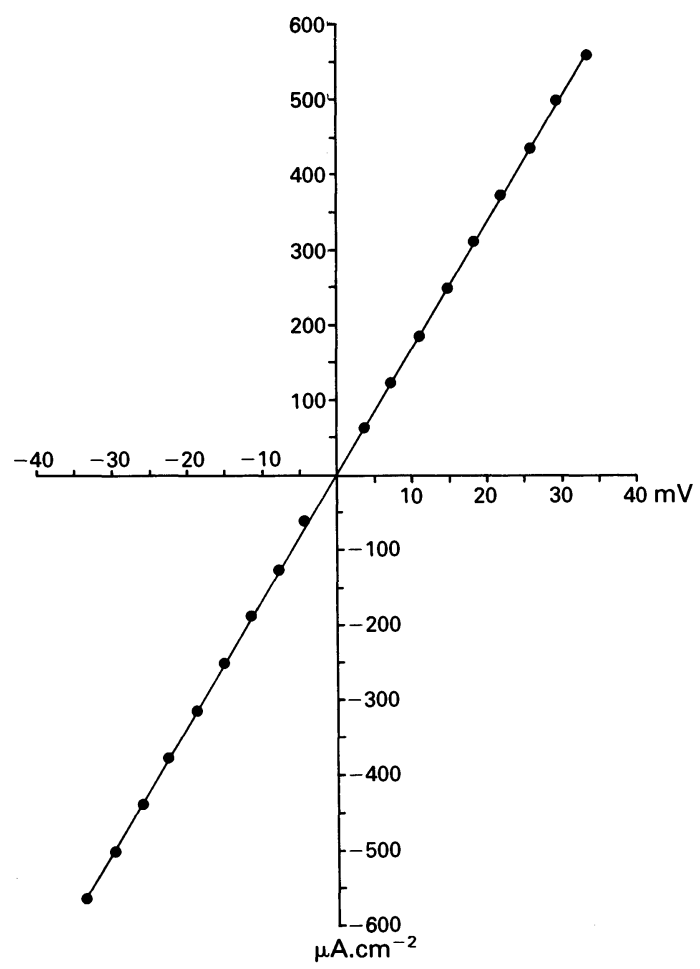

Fig. 6. The relationship between current and voltage in the pig follicle wall as obtained in a voltage clamp experiment (for method see Civan, 1983). The current required to maintain a predetermined voltage was measured and the transmural resistance has been calculated using Ohm's Law (see Table 4). The open circuit voltage and short-circuit current are found at the intersections between the line and the $x$ and $y$ co-ordinates, respectively: these are close to zero in this structure.

epithelia (Widdicombe et al., 1987), should not be regarded as contradictory evidence because the direction of transport is the opposite of that of absorptive epithelia.

The movement of ions across a membrane can establish a transmural potential difference which can be measured electrophysiologically to provide evidence of active transport. When this voltage is electronically clamped to zero the current passing ('short-circuit current') indicates the direction and net movement of charged particles which can then be identified by inhibiting transport mechanisms (Ussing \& Zerahn, 1951; Civan, 1983). This method has become conventional for studying transport processes in epithelia and has now been applied to the isolated follicle wall of the pig. The open-circuit potential difference (i.e. unclamped) was found to range from +0.5 to $-0.5 \mathrm{mV}$ and the short-circuit current was close to zero (Fig. 6). These data provide no support for the active transport hypothesis, but nor do they deny it. McCaig $(1980,1985)$ has tackled the same question by the alternative approach of measuring the potential difference of superfused mouse follicles using microelectrodes. As the microelectrode advanced, voltage changes were encountered: firstly as surface epithelial and granulosa cells were traversed successively, in which the membrane potentials were $-21.9 \pm 0.4 \mathrm{mV}$, and finally, as the potential difference fell to $+1.2 \pm 0.3 \mathrm{mV}$, when the antrum was entered (Fig. 7). This small antral potential difference became more positive near the time of ovulation or after treatment with metabolic inhibitors. Since the resistance did not change concomitantly it was inferred that active transport was responsible for the difference. 


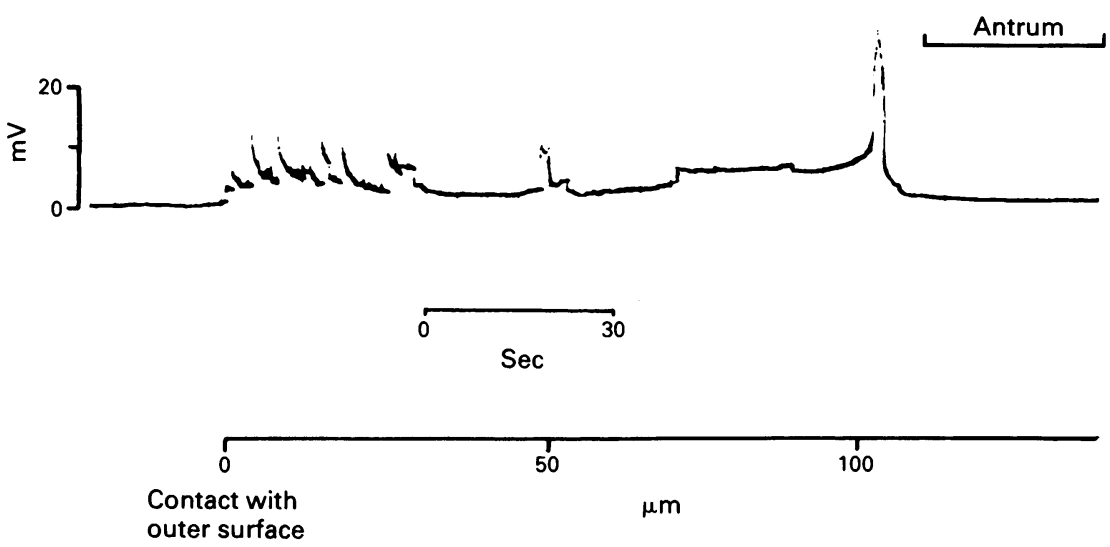

Fig. 7. Electrical potentials recorded using a glass microelectrode traversing the wall of a mouse follicle and entering the antrum. A number of intracellular potentials (negative-going, upward deflections) are recorded before a steady, slightly positive potential is reached in the antrum (McCaig, 1980).

Since there are transmural differences in the concentrations of relatively impermeable charged molecules (proteins and glycosaminoglycans) conditions favour the existence of a Gibbs-Donnan equilibrium. The small (if significant) transmural potential differences could therefore have developed merely from diffusion of the major ions. The equilibrium potentials for these ions can be calculated from their concentrations on either side of the follicle wall using the Nernst equation, assuming that the activity coefficients are the same in the two fluids (Borland et al., 1977). The potentials corresponding to our data from the pig are: $\mathrm{Na},-0.69 \pm 0.05 \mathrm{mV}, \mathrm{K},+0.32 \pm$ $1.64 \mathrm{mV}, \mathrm{Cl},-0.40 \pm 0.47 \mathrm{mV}$. These are consistent with the measured electrical potentials. They do not, however, rule out active transport because leaky membranes are less able to hold a charge. Definitive testing of active transport will require direct measurement of $\mathrm{Na}^{+}$and $\mathrm{Cl}^{-}$ fluxes.

The specific electrical resistance of the follicle wall can be calculated from the relationship between the transmural potential difference and the current being passed (Fig. 6). This relationship is linear which indicates that the follicle wall behaves as a simple ohmic conductor without significant rectification. It is concluded that the current is probably conducted by a paracellular rather than a

Table 4. Comparison of electrical properties of the ovarian follicular wall with those other mammalian epithelial cells

\begin{tabular}{|c|c|c|c|c|}
\hline Epithelium & Species & Classification & $\begin{array}{l}\text { Specific } \\
\text { resistance } \\
\left(\Omega \mathrm{cm}^{2}\right)\end{array}$ & Reference \\
\hline $\begin{array}{l}\text { Ovarian follicle } \\
\text { (unstripped) }\end{array}$ & $\begin{array}{l}\text { Mouse } \\
\text { Pig }\end{array}$ & Leaky & $\begin{array}{l}49 \\
60\end{array}$ & $\begin{array}{l}\text { McCaig (1980) } \\
\text { R.G. Gosden \& R.H.F. Hunter } \\
\text { (unpublished) }\end{array}$ \\
\hline Trophectoderm & Rabbit & Tight & 2650 & Cross (1973) \\
\hline Proximal convoluted tubule & Dog & Leaky & 6 & Boulpaep \& Seely (1971) \\
\hline Ileum (unstripped) & Rabbit & Leaky & 89 & Field et al. (1971) \\
\hline Gall bladder & Rabbit & Leaky & 28 & Frömter \& Diamond (1972) \\
\hline
\end{tabular}


transcellular route, which is consistent with the evidence that hydrated channels exist between the cells. The follicle wall resistance is sufficiently low that the epithelium can be classified with those that are electrically 'leaky' (Table 4). This resistance is in fact the sum of the resistance of the ovarian surface epithelium and the follicle itself, of which the latter may be the minor component.

Up to this point it has been assumed for the sake of argument that the total number of particles present (i.e. osmotic potential) determines the rate and direction of net water transport. Chemical potential is, however, influenced by differences in temperature and hydrostatic pressure (Patton, 1965). Whilst it might not be expected a priori that the temperature inside follicles would be different from that of the body core, the surprising claim has been made that rabbit follicles have a temperature $2-3^{\circ} \mathrm{C}$ lower than the ovarian stroma (Grinsted et al., 1980). If substantiated, this finding adds another, albeit minor, factor to the list of those responsible for the formation of follicular fluid.

Finally, it is necessary to discuss critically the evidence for transudation. The follicle wall is very permeable to water (Peckham \& Kiekhofer, 1959) and although the hydraulic conductivity of granulosa cells has never been measured, it is assumed that most water enters is paracellularly. Transudation requires a hydrostatic pressure gradient from capillary to antrum although the pressures have been found to be similar $(\sim 17 \mathrm{mmHg}$ ) (Blandau \& Rumery, 1963; Espey \& Lipner, 1963; Rondell, 1964). Accurate measurement under physiological conditions is difficult and small, undetectable gradients could still account for the slow accumulation of follicular water. According to this hypothesis, a change in interstitial pressure, perhaps under the influence of hormones, would lead to swelling of the follicle which would bulge into the lower pressure region of the ovarian bursa or peritoneal cavity, as occurs when the ovarian vein is experimentally clamped to raise intravascular pressure. There is evidence of stromal oedema and increasing leakiness of the thecal capillaries during the periovulatory period (Morris \& Sass, 1966; Byskov, 1969; Bjersing \& Cajander, 1974), but the existence of pressure gradients remains to be demonstrated.

Transudation provides the most satisfactory explanation for the formation of secondary follicular fluid which is occurring relatively rapidly. It might be argued, however, that it is an unwieldy force for the morphogenesis of the antral follicle and for the controlled production of primary fluid. That other mechanisms are involved at early stages of development may be inferred from studies of mouse ovaries in organ culture in which follicles were found to undergo formation and limited expansion of the antrum in the presence of FSH (Ryle, 1969). Since a vascular supply was absent it seems likely that antrum formation requires active secretion. It is not clear whether any secondary fluid can be produced under similar conditions although this appears to be doubtful because rat ovaries ovulating in vitro did not undergo a normal increase in weight (Osman \& LieuwmaNoordanus, 1980).

Throughout much of this review, there has been an assumption that follicular fluid is homogeneous whereas, in reality, microenvironments undoubtedly exist. Not only would these be anticipated in the vicinity of the oocyte and its investment of cumulus cells but also within the mural granulosa cell layers as a result of local metabolism/secretion and fluxes across the follicle wall. And even within the antrum unstirred layers may be encouraged by mucification. A major focus of future research should therefore be the charting of these differences.

\section{Conclusions}

The composition of follicular fluid in Graafian follicles is similar but not identical to ovarian venous plasma. Differences between the two fluids are attributed to a blood-follicle barrier, which restricts the passage of large molecules, and to the existence of a hypothetical active transport mechanism and/or a Donnan equilibrium, reflected by the distribution of small permeant ions. The follicle epithelium has been characterized as 'leaky' on the basis of both chemical and electrical criteria. 
The rate of follicular fluid accumulation is much greater during preovulatory activation of the follicle (secondary fluid) than at preceding stages (primary fluid), suggesting that gonadotrophic hormones have a major influence on the rate of swelling. The evidence for water transport following an osmotic gradient set up by active transport of $\mathrm{Na}^{+}$has been inconclusive. The conventional view that fluid forms from transudation of plasma rests on circumstantial evidence and is less likely to account for primary than for secondary fluid. The discussion has focussed on the fluid in the antrum principally because so little is known about the fluids which lie in the narrow extracellular spaces and bathe the granulosa cells and oocyte. A major challenge for future research will be elucidation of the compositions of these microenvironments which, in contrast to the bulky antral fluid which will buffer change, should be sensitive indicators of fluctuating biosynthetic activity and of optimal conditions for cell culture.

We thank Kay Grant and Robert Nichol for technical assistance and Dr Colin McCaig for helpful discussion and permission to reproduce some of his results. Financial support has been generously provided by the Medical Research Council, Agriculture and Food Research Council and the Wellcome Trust.

\section{References}

Albertini, D.F. \& Anderson, E. (1974) The appearance of intercellular connections during the ontogeny of the rabbit ovarian follicle with particular reference to gap junctions. J. Cell Biol. 63, 234-250.

Ax, R.L. \& Ryan, R.J. (1979) The porcine follicle. IV. Mucopolysaccharides at different stages of development. Biol. Reprod. 20, 1123-1132.

Baukloh, V., Bohnet, H.G., Trapp, M., Heeschen, W., Feichtinger, W. \& Kemeter, P. (1985) Biocides in human follicular fluid. Ann. New York Acad. Sci. 442, 240-250.

Bjersing, L. \& Cajander, S. (1974) Oviulation and the mechanism of follicle rupture. VI. Ultrastructure of theca interna and the inner vascular network surrounding rabbit Graafian follicles prior to induced ovulation. Cell Tissue Res. 153, 31-44.

Blandau, R.J. \& Rumery, R.E. (1963) Measurements of intrafollicular pressure in ovulatory and preovulatory follicles of the rat. Fert. Steril. 14, 330-341.

Borland, R.M., Biggers, J.D. \& Lechene, C.P. (1977) Studies on the composition and formation of mouse blastocoele fluid using electron probe microanalysis. Devl Biol. 55, 1-8.

Borland, R.M., Biggers, J.D., Lechene, C.P. \& Taymor, M.L. (1980) Elemental composition of fluid in the human Fallopian tube. J. Reprod. Fert. 58, 479-482.

Boulpaep, E.L. \& Seely, J.F. (1971) Electrophysiology of proximal and distal tubules in the autoperfused dog kidney. Am. J. Physiol. 221, 1084-1096.

Brambell, F.W.R. (1956) Ovarian changes. In Marshall's Physiology of Reproduction, 3rd edn, Vol. I, Pt. 1, pp. 397-542. Ed. A. S. Parkes. Longmans, Green \& Co., London.

Burgoyne, P.S., Borland, R.M., Biggers, J.D. \& Lechene, C.P. (1979) Elemental composition of rabbit antral fluid during preovulatory follicular swelling. $J$. Reprod. Fert. 57, 515-523.

Burr, J.H., Jr \& Davies, J.I. (1951) The vascular system of the rabbit ovary and its relationship to ovulation. Anat. Rec. 111, 273-297.
Byskov, A.G.S. (1969) Ultrastructural studies on the preovulatory follicle in the mouse ovary. Z. Zellforsch. mikrosk. Anat. 100, 285-299.

Chang, S.C.S., Jones, J.D., Ellefson, R.D. \& Ryan, R.J. (1976) The porcine ovarian follicle. 1. Selected chemical analysis of follicular fluid at different developmental stages. Biol. Reprod. 15, 321-328.

Chong, A.P., Taymor, M.L. \& Lechene, C.P. (1977) Electron probe microanalysis of the chemical elemental content of human follicular fluid. Am. J. Obstet. Gynec. 128, 209-211.

Civan, M.M. (1983) Epithelial Ions and Transport. Application of Biophysical Techniques. Wiley, New York.

Cran, D.G., Moor, R.M. \& Hay, M.F. (1976) Permeability of ovarian follicles to electron-dense macromolecules. Acta endocr., Copen., 82, 631-636.

Cross, M.H. (1973) Active sodium and chloride transport across the rabbit blastocoele wall. Biol. Reprod. 8, 566-575.

David, A., Frenkel, G. \& Kraicer, P.F. (1973) Chemical composition of rabbit follicular fluid. Fert. Steril. 24, 227-229.

Driancourt, M.A., Gauld, I.K., Terqui, M. \& Webb, R. (1986) Variations in patterns of follicle development in prolific breeds of sheep. J. Reprod. Fert. 78, 565-575.

Edwards, R.G. (1974) Follicular fluid. J. Reprod. Fert. 37, 189-219.

Espey, L.L. \& Lipner, H. (1963) Measurements of intrafollicular pressures in the rabbit ovary. Am.J. Physiol. 205, 1067-1072.

Field, M., Fromm, D. \& McColl, I. (1971) Ion transport in rabbit ileal mucosa. I. $\mathrm{Na}$ and $\mathrm{Cl}$ fluxes and shortcircuit current. Am. J. Physiol. 270, 1388-1396.

Fraser, I., Baird, D.T. \& Cockburn, F. (1973) Ovarian venous blood $\mathrm{PO}_{2}, \mathrm{PCO}_{2}$ and $\mathrm{pH}$ in women. $J$. Reprod. Fert. 33, 11-17.

Frömter, E. \& Diamond, J. (1972) Route of passive ion permeation in epithelia. Nature, New Biol. 235, 9-13.

Goldenberg, R.L., Vaitukaitis, J.L. \& Ross, G.T. (1972) Estrogen and follicle stimulating hormone inter- 
actions on follicle growth in rats. Endocrinology 90, 1492-1498.

Gosden, R.G. \& Byatt-Smith, J.G. (1986) Oxygen concentration gradient across the ovarian follicular epithelium: model, predictions and implications. Hum. Reprod. 1, 65-68.

Gosden, R.G. \& Telfer, E. (1987) Scaling of follicular size in mammalian ovaries. J. Zool., Lond. 211, 157-168.

Gosden, R.G., Laing, S.C., Flurkey, K. \& Finch, C.E. (1983) Graafian follicle growth and replacement in anovulatory ovaries of ageing $\mathrm{C} 57 \mathrm{BL} / 6 \mathrm{~J}$ mice. $J$. Reprod. Fert. 69, 453-462.

Grinsted, J., Blendstrup, K., Andreasen, M.P. \& Byskov, A.G. (1980) Temperature measurements of rabbit antral follicles. J. Reprod. Fert. 60, 149-155.

Hadek, R. (1963) Electron microscope study on primary liquor foliculi secretion in the mouse ovary. $J$. Ultrastruct. Res. 9, 445-458.

Knudsen, J.F., Litkowski, L.J., Wilson, T.L., Guthrie, H.D. \& Batta, S.K. (1978) Concentrations of hydrogen ions, oxygen, carbon dioxide and bicarbonate in porcine follicular fluid. J. Endor. 79, 249-250.

Knudsen, J.F., Litkowski, L.J., Wilson, T.L., Guthrie, H.D. \& Batta, S.K. (1979) Follicular fluid electrolytes and osmolality in cyclic pigs. J. Reprod. Fert. 57, 419-422.

Laing, S.C., Gosden, R.G. \& Fraser, H.M. (1984) Cytogenetic analysis of mouse oocytes after experimental induction of follicular overripening. J. Reprod. Fert. 70, 387-393.

Lenton, E. (1988) The endocrine environment of the oocyte. J. Reprod. Fert. 82, 827-841.

McCaig, C.D. (1980) Electrophysiological and electron microscopical investigations of mouse ovarian follicle and periovarian membrane. Ph.D. thesis, University of Glasgow.

McCaig, C.D. (1985) A potential difference across mouse ovarian follicle. Experientia 41, 609-611.

McNatty, K.P. (1978) Follicular fluid. In The Vertebrate Ovary, pp. 215-259. Ed. R. E. Jones. Plenum, New York.

McNatty, K.P., Hunter, W.M., McNeilly, A.S. \& Sawers, R.S. (1975) Changes in the concentration of pituitary and steroid hormones in the follicular fluid of human Graafian follicles throughout the menstrual cycle. $J$. Endocr. 64, 555-571.

McNatty, K.P., Moore Smith, D., Makris, A., Osathanondh, R. \& Ryan, R.J. (1979) The microenvironment of the human antral follicle: interrelationships among steroid levels in antral fluid, the population of granulosa cells, and the status of the oocyte in vivo and in vitro. J. clin. Endocr. Metab. 49, $851-860$.

Morris, B. \& Sass, M.B. (1966) The formation of lymph in the ovary. Proc. R. Soc. Lond. B 164, 577-591.

Mossman, H.W. \& Duke, K.L. (1973) Comparative Morphology of the Mammalian Ovary. University of Wisconsin Press, Madison.

Olds, D. \& VanDemark, N.L. (1957) Composition of luminal fluids in bovine female genitalia. Fert. Steril. 8, 345-354.

Osman, P. \& Lieuwma-Noordanus, C. (1980) Ovulation from rat and hamster ovaries in vitro. J. Reprod. Fert. 59, 431-436.

Parkes, A. S. (1932) Size of Graafian follicle at ovulation. Proc. R. Soc. B 109, 185-213.

Patton, A.R. (1965) Biochemical Energetics and Kinetics. W.B. Saunders Co., Philadelphia.

Payer, A.F. (1975) Permeability of ovarian follicles and capillaries in mice. Am. J. Anat. 142, 295-318.

Peckham, B. \& Kiekhofer, W. (1959) The movement of tritium-labelled water in the human ovarian follicle. Am. J. Obstet. Gynec. 78, 1012-1018.

Ramsay, J.A. \& Brown, R.H.J. (1955) Simplified apparatus and procedure for freezing-point determinations upon small volumes of fluid. J. scient. Instrum. 32, $372-375$.

Robinson, A. (1918) The formation, rupture, and closure of ovarian follicles in ferrets and ferret-polecat hybrids, and some associated phenomena. Trans. $R$. Soc. Edin. 52, 303-362.

Rondell, P. (1964) Follicular pressure and distensibility in ovulation. Am. J. Physiol. 207, 590-594.

Ryle, M. (1969) Morphological responses to pituitary gonadotrophins by mouse ovaries in vitro. J. Reprod. Fert. 20, 307-312.

Schuetz, A.W. \& Anisowicz, A. (1974) Cation and protein composition of ovarian follicular fluid of the pig. Relation to follicle size. Biol. Reprod. 11, 64-72.

Shalgi, R., Kraicer, P.F. \& Soferman, N. (1972) Gases and electrolytes of human follicular fluid. J. Reprod. Fert. 28, 335-340.

Shalgi, R., Kraicer, P., Rimon, A., Pinto, M. \& Soferman, N. (1973) Proteins of human follicular fluid: the blood-follicle barrier. Fert. Steril. 24, 429- 434.

Spring, K.R. \& Ericson, A.-C. (1982) Epithelial cell volume modulation and regulation. J. Membrane Biol. 69, 167-176.

Turnbull, K.E., Braden, A.W.H. \& Mattner, P.E. (1977) The pattern of follicular growth and atresia in the ovine ovary. Aust. J. biol. Sci. 30, 229-241.

Ussing, H. \& Zerahn, K. (1951) Active transport of sodium as the source of electric current in the shortcircuited isolated frog skin. Acta physiol. scand. 23, 110-127.

Weir, B.J. (1971) The reproductive organs of the female plains viscacha, Lagostomus maximus. J. Reprod. Fert. 25, 365-373.

Widdicombe, J.H., Coleman, D.L., Finkbeiner, W.E. \& Friend, D.S. (1987) Primary cultures of the dog's tracheal epithelium: fine structure, fluid, and electrolyte transport. Cell Tissue Res. 247, 95-103.

Zachariae, F. (1957) Studies on the mechanism of ovulation. Autoradiographic investigations on the uptake of radioactive sulphate $\left({ }^{35} \mathrm{~S}\right)$ into the ovarian follicular mucopolysaccharides. Acta endocr., Copenh. 26, 215-224.

Zachariae, F. (1958) Studies on the mechanism of ovulation. Permeability of the blood-liquor barrier. Acta endocr., Copenh. 27, 339-342.

Zachariae, F. \& Jensen, C.E. (1958) Studies on the mechanism of ovulation. Histochemical and physicochemical investigations on genuine follicular fluids. Acta. endocr., Copenh. 27, 343-355. 